\title{
PENGARUH GAYA KEPEMIMPINAN DAN DISIPLIN KERJA TERHADAP KINERJA KARYAWAN DENGAN MOTIVASI KERJA SEBAGAI VARIABEL INTERVENING PADA PT. SEMEN PADANG
}

\author{
Rudi Islami, Riri Mayliza \\ Sekolah Tinggi Ilmu Ekonomi "KBP" \\ ririmayliza@akbpstie.ac.id \\ rudiislami95@gmail.com
}

\begin{abstract}
This research was conducted in order to determine the effect of leadership style and work discipline on employee performance mediated by motivation at PT. Semen Padang. The instrument used in this study was a questionnaire consisting of a number of statements about leadership style, work discipline, employee performance and motivation. This study used a sample of saturated, whereby the entire study population will be selected into the sample as many as 95 people. Data analysis techniques used in this study is a simple linear regression test. Simple linear regression test is used to determine the effect of leadership style on motivation, work discipline influence on the motivation, the effect of performance on motivation, leadership style influence on the performance mediated by motivation and influence of labor discipline on performance mediated by motivation. The results showed that the leadership style positive and significant effect on the motivation, discipline positive and significant effect on the motivation, performance positive and significant impact on motivation, leadership style positive and significant effect on performance mediated by motivation and discipline positive and significant impact on performance mediated by motivation.
\end{abstract}

Keywords: leadership style, discipline, performance, motivation

\section{PENDAHULUAN}

Pergerakan roda suatu organisasi sangat ditentukan oleh faktor kepemimpinan. Kepemimpinan merupakan hal yang dominan dalam suatu organisasi karena kepemimpinan bukan saja melakukan perencanaan ataupun pelaksanaan jalanya organisasi, tetapi juga dapat mengorganisir anggota dalam mencapai tujuan organisasi. Salah satu permasalahan manajemen yang bersifat kritis pada saat ini adalah kepemimpinan karena mampu atau tidak mampunya seseorang pemimpin dapat melaksanakan tugas nya sebagai pemimpin suatu organisasi dan adanya pemimpin yang kurang dihargai oleh bawahanya.

Dalam era globalisasi sekarang ini, keahlian memimpin diperlukan organisasi, seiring dengan kemajuan zaman dan kompleksitas dunia bisnis dan pemerintahan, kepemimpinan semakin memegang peran yang penting dan 
berfungsi sebagai motor penggerak bagi organisasi dalam mencapai tujuan. Disisi lain tenaga kerja merupakan salah satu asset perusahaan yang paling utama, dari itu tenaga kerja perlu dibina secara baik dari seorang pemimpin. Pembinaan yang baik dapat menciptakan tenaga kerja yang mempunyai komitmen dan kegairahan dalam pekerjaan serta mempunyai komitmen organisasi yang tinggi sehingga kinerja kerja dapat ditingkatkan.

Peningkatan kinerja karyawan akan membawa kemajuan bagi perusahaan untuk dapat bertahan dalam suatu persaingan lingkungan bisnis yang tidak stabil. Oleh karena itu upaya-upaya untuk meningkatkan kinerja karyawan merupakan tantangan manajemen yang paling serius karena keberhasilan untuk mencapai tujuan dan kelangsungan hidup perusahaan tergantung pada kualitas kinerja sumber daya manusia yang ada didalamnya.

PT Semen Padang (Perusahaan) didirikan pada tanggal 18 Maret 1910 dengan nama NV Nederlandsch Indische Portland Cement Maatschappij (NV NIPCM) yang merupakan pabrik semen pertama di Indonesia. Kemudian pada tanggal 5 Juli 1958 Perusahaan dinasionalisasi oleh pemerintah Republik Indonesia dari pemerintah Belanda. Penelilitan ini difokuskan pada karyawan PT Semen Padang bagian Personalia yang berlokasi di jalan Raya Indarung kota Padang Sumatera Barat.

Kinerja karyawan yang tinggi sangatlah diharapkan oleh perusahaan tersebut. Semakin banyak karyawan yang mempunyai kinerja tinggi, maka produktivitas perusahaan secara keseluruhan akan meningkat sehingga perusahaan akan dapat bertahan dalam persaingan global dan MEA.

Karyawan dituntut untuk mampu menyelesaikan tugas dan tanggung jawabnya secara efektif dan efisien . Keberhasilan karyawan dapat diukur melalui kepuasan konsumen, berkurangnya jumlah keluhan dan tercapainya target yang optimal. Kinerja karyawan PT Semen Padang juga dapat diukur melalui penyelesaian tugasnya secara efektif dan efisien serta melakukan peran dan fungsinya dan itu semua berhubungan linear dan berhubungn positif bagi keberhasilan bagi suatu perusahaan.

Terdapat faktor negatif yang dapat menurunkan kinerja karyawan, diantaranya adalah menurunya keinginan karyawan untuk mencapai prestasi kerja, kurangnya ketepatan waktu dalam penyelesaian pekerjaan sehingga kurang menaati peraturan, pengaruh yang berasal dari lingkungan kerja sekitar, teman sekerja yang juga menurun semangatnya dan tidak adanya contoh yang akan dijadikan acuan dalam pencapain prestasi yang baik. Semua itu merupakan sebab menurunya kinerja karyawan dalam bekerja. Faktor-faktor yang dapat digunakan untuk meningkatkan kinerja diantaranya adalah gaya kepemimpinan, motivasi dan disiplin kerja.

\section{LANDASAN TEORI DAN HIPOTESIS}

Kepemimpinan merupakan tulang punggung pengembangan organisasi karenatanpa kepemimpinan yang baik akan sulit mencapai tujuan organisasi. Jika seorangpemimpin berusaha untuk mempengaruhi perilaku orang lain, maka orang tersebutperlu memikirkan gaya kepemimpinannya. Gaya kepemimpinan adalah bagaimanaseorang pemimpin melaksanakan fungsi kepemimpinannya dan bagaimana ia dilihatoleh mereka yang berusaha dipimpinnya atau mereka yang mungkin sedangmengamati dari luar (Robert, 1992). James et. al. (1996) 
mengatakan bahwa gayakepemimpinan adalah berbagai pola tingkah laku yang disukai oleh pemimpin dalamproses mengarahkan dan mempengaruhi pekerja. Gaya kepemimpinan adalahperilaku dan strategi, sebagai hasil kombinasi dari falsafah, keterampilan, sifat, sikap,yang sering diterapkan seorang pemimpin ketika ia mencoba mempengaruhi kinerjabawahannya (Tampubolon, 2007).

Berdasarkan definisi gaya kepemimpinan diatas dapat disimpulkan bahwakepemimpinan adalah kemampuan seseorang dalam mengarahkan, mempengaruhi,mendorong dan mengendalikan orang lain atau bawahan untuk bisa melakukan sesuatu pekerjaan atas kesadarannya dan sukarela dalam mencapai suatu tujuantertentu.

Menurut Simamora (1997) disiplin adalah prosedur yang mengoreksi ataumenghukum bawahan karena melanggar peraturan atau prosedur. Disiplinkerjaadalah suatu alat yang digunakan para manajer untuk berkomunikasi dengankaryawan agar mereka bersedia untuk mengubah suatu perilaku serta sebagai suatuupaya untuk meningkatkan kesadaran dan kesediaan seseorang menaati semuaperaturan perusahaan dan norma-norma sosial yang berlaku (Rivai, 2004).

Hasibuan (2004) berpendapat bahwa kedisiplinan adalah kesadaran dankesediaan seseorang menaati semua peraturan perusahaan dan norma-norma sosialyang berlaku.Berdasarkan pengertian diatas disimpulkan bahwa disiplin kerja merupakansuatu sikap, tingkah laku, dan perbuatan yang sesuai dengan peraturan baik tertulismaupun tidak tertulis, dan bila melanggar akan ada sanksi atas pelanggarannya.

Kinerja merupakan perilaku organisasi yang secara langsung berhubungandengan produksi barang atau penyampaian jasa. Informasi tentang kinerja organisasi merupakan suatu hal yang sangat penting digunakan untuk mengevaluasi apakah proses kinerja yang dilakukan organisasi selama ini sudah sejalan dengan tujuan yang diharapkan atau belum. Akan tetapi dalam kenyataannya banyak organisasi yang justru kurang atau bahkan tidak jarang ada yang mempunyai informasi tentang kinerja dalam organisasinya.

Kinerja sebagai hasil-hasil fungsi pekerjaan/kegiatan seseorang atau kelompok dalam suatu organisasi yang dipengaruhi oleh berbagai faktor untuk mencapai tujuan organisasi dalam periode waktu tertentu (Tika, 2006). Sedangkan menurut Rivai dan Basri (2005) kinerja adalah kesediaan seseorang atau kelompok orang untuk melakukan sesuatu kegiatan dan menyempurnakannya sesuai dengan tanggung jawab dengan hasil seperti yang diharapkan.

Menurut Malthis (2001) motivasi merupakan hasrat didalam diri seseorangyang menyebabkan orang tersebut melakukan tindakan. Sedangkan Rivai (2004)berpendapat bahwa motivasi adalah serangkaian sikap dan nilai-nilai yangmempengaruhi individu untuk mencapai hal yang spesifik sesuai dengan tujuanindividu. Motivasi adalah kesediaan melakukan usaha tingkat tinggi guna mencapaisasaran organisasi yang dikondisikan oleh kemampuan usaha tersebut memuaskankebutuhan sejumlah individu (Robins dan Mary, 2005).

Motivasi merupakan faktor psikologis yang menunjukan minat individuterhadap pekerjaan, rasa puas dan ikut bertanggung jawab terhadap aktivitas ataupekerjaan yang dilakukan (Masrukhin dan Waridin, 2004). Sedangkan Hasibuan(2004) berpendapat bahwa motivasi adalah hal yang menyebabkan, menyalurkan danmendukung perilaku manusia, supaya mau 
bekerja giat dan antusias mencapai hasilyang optimal. Motivasi merupakan sesuatu yang membuat bertindak atau berperilakudalam cara-cara tertentu (Armstrong, 1994).Berdasarkan pengertian diatas disimpulkan bahwa motivasi merupakankegiatan yang mengakibatkan, menyalurkan, memelihara dan mendorong perilakumanusian.

Berdasarkan pada landasan teori dan kerangka pemikiran di atas,maka hipotesis maka penelitian ini adalah :

$\mathrm{H}_{1}$ : Gaya kepemimpinan berpengaruh positif terhadap motivasi kerja.

$\mathrm{H}_{2}$ : Disiplin kerja berpengaruh positif terhadap motivasi kerja.

$\mathrm{H}_{3}$ :Motivasi kerja berpengaruh positif terhadap kinerja karyawan.

$\mathrm{H}_{4}$ :Gaya kepemimpinan berpengaruh positif terhadap kinerja karyawan yang dimediasi oleh motivasi kerja

$\mathrm{H}_{5}$ :Disiplin kerja berpengaruh positif terhadap kinerja karyawan yang dimediasi oleh motivasi kerja

\section{METODOLOGI PENELITIAN}

Berdasarkan permasalahan yang akan diteliti pada penelitian ini maka jenis penelitian kuantitatif yang bersifat kausatif dimana berbicara dengan angka-angka serta melihat pengaruh antara variabel bebas (independen) dengan variabel terikat (dependen) Sugiyono 2009. Pada penelitian ini peneliti ingin melihat pengaruh gaya kepemimpinan dan disiplin kerja terhadap kinerja karyawan dengan motivasi kerja sebagai variabel intervening. Maka dari itu peneliti tertarik untuk mengambil data di PT Semen Padang yang beralamat di Jalan Raya Indarung Sumatera Barat yang bergerak dibidang produksi semen.

Populasi adalah wilayah generalisasi yang terdiri dari objek atau subjek yang menjadi kuantitas dan karakteristik tertentu yang ditetapkan oleh peneliti untuk dipelajari dan kemudian ditarik kesimpulannya (Sugiyono, 2009). Populasi dalam penelitian ini adalah seluruh karyawan yang ada di PT Semen Padang yang berjumlah 1753 orang, namun data diambil di Biro Perencanaan \& Pengembangan SDM.

Sampel adalah bagian dari jumlah dan kharaktristik yang dimiliki oleh populasi tersebut. Sampel yang diambil dari populasi ini harus representatif atau yang mewakili ( Sugiyono, 2013).

Penentuan sampel yang digunakan dalam penelitian ini adalah simple insidential atau sampling incidental karena tekhnik penentuan sampel berdasarkan kebetulan, yaitu siapa saja yang secara kebetulan/incidental bertemu dengan peneliti dapat digunakan sebagai sampel bila dipandang orang yang kebetulan ditemui cocok sebagai sumber data (Sugiyono, 2013). Jumlah sampel dengan menggunakan rumus Slovin (Umar, 2007):

$$
\mathrm{n}=\frac{\mathrm{N}}{1+\mathrm{N}(e)^{2}}
$$

Dimana :

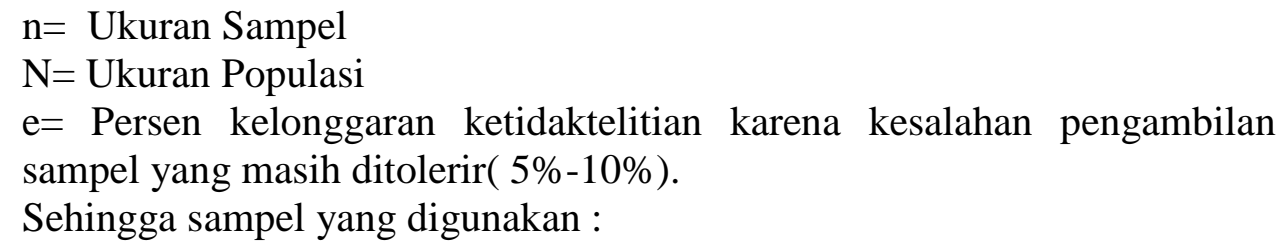




$$
\begin{aligned}
& \overline{1+1753(10)^{2}} \\
= & 94,60 \\
= & 95 \text { Sample }
\end{aligned}
$$

Berdasarakan perhitungan diatas sampel yang diambil dalam penelitian ini sebesar 95 sampel karyawan yang ada pada biro personalia PT. Semen Padang. Teknik Analisa Data yang digunakan pada penelitian ini adalah Uji Validitas dan Realibilitas. Uji validitas menurut Nugroho ( 2005: 67 ) digunakan untuk mengetahui kelayakan butir - butir dalam daftar pertanyaan atau pernyataan dalam mendefinisikan variabel. Daftar pernyataan ini pada umumnya mendukung suatu kelompok variabel tertentu.

Jadi dapat dikatakan, semakin tinggi validitas suatu alat ukur maka alat ukur tersebut semakin mengenai pada sasarannya atau semakin menunjukan apa yang seharusnya diukur. Suatu alat ukur dapat dikatakan mempunyai validitas tinggi apabila dapat dijalankan fungsi ukurnya atau memberikan hasil ukur yang sesuai dengan maksud dan tujuan dari diadakannya tes atau penilaian tersebut.

Validitas suatu butir pernyataan dapat dilihat pada hasil output statistical program for social science ( SPSS) pada tabel dengan judul item-total statistic. Menilai kevalidtan masing - masing butir pernyataan dapat dilihat dari nilai corrected item-total correlationmasing - masing butirpernyataan. Suatu butir pernyataan dikatakan valid jika nilai dari corrected item-total correlation $>0,300$. Uji validitas sebaiknya dilakukan secara terpisah pada lembar kerja yang berbeda antara satu konstruk variabel dengan konstruk variabel lain sehingga dapat diketahui butir - butir variabel mana yang paling banyak tidak valid. Sehingga pengambilan keputusan adalah :

jika corrected item-total correlation $>0,300$ maka dimensi tersebut valid.

jika corrected item-total correlation $\leq 0,300$ maka dimensi tersebut tidak valid.

Uji reliabilitas ( keandalan ) menurut Nugruho ( $2005: 72$ ) merupakan ukuran suatu kestabilan dan konsistensi responden dalam menjawab hal yang berkaitan dengan pernyataan yang merupakan dimensi suatu variabel dan disusun dalam suatu bentuk koesioner.

Uji reabilitas dapat dilakukan secara bersama - sama terhadap seluruh butir pernyataan untuk lebih dari satu variabel, namun sebaiknya uji reliabilitas sebaliknya dilakukan pada masing - masing variabel pada lembar kerja yang berbeda sehingga dapat diketahui konstruk variabel mana yang tidak reliabel. Reliabilitas suatu konstuk variabel dikatakan baik jika memiliki nilai Cronbach's Alpha $>0,06$. Sehingga pengambilan keputusan adalah :

a. Jika r Alpha positif, serta $r>0,06$ maka dimensi tersebut reliabel.

b. Jika r Alpha positif, serta $r \leq 0,06$ maka dimensi tersebut tidak reliabel.

Uji t digunakan untuk menguji koefisien regresi secara parsial dari variabel bebas terhadap variabel terikat. Pengujian ini menggunakan tingkat resiko sebesar $5 \%(\alpha=0,05)$.

Uji Normalitas dilakukan untuk menguji apakah dalam sebuah model regresi variabel independen dan variabel dependenmemiliki ditribusi normal atau tidak. Data dikatakan berdistribusi normal apabila Asymp Sig (2-tailed )lebih besar dari level of significant yang dipakai yaitu 0,05 .

Analisa regresi linear sederhana adalah suatu teknik statistik yang digunakan untuk mengetahui seberapa besar pengaruh variabel bebas terhadap variabel terikat, dimana tujuan menggunakan analisa regresi sederhana pada penelitian ini 
adalah untuk mengetahui pengaruh pengaruh gaya kepemimpinan terhadap motivasi, pengaruh disiplin kerja terhadap motivasi, pengaruh kinerja terhadap motivasi, pengaruh gaya kepemimpinan terhadap kinerja yang dimediasi oleh motivasi dan pengaruh disiplin kerja terhadap kinerja yang dimediasi oleh motivasi dengan persamaan sebagai berikut :

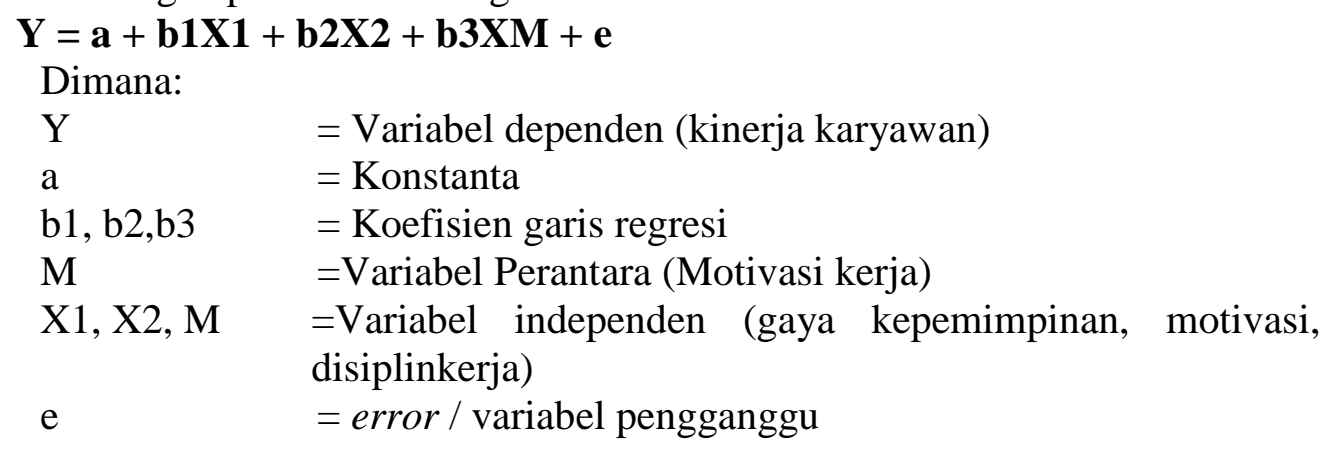

\section{HASIL DAN PEMBAHASAN}

Tabel 1

Hasil Uji Variabel Gaya Kepemimpinan (X1)

Item-Total Statistics

\begin{tabular}{|l|c|c|c|}
\hline & $\begin{array}{c}\text { Scale Mean if Item } \\
\text { Deleted }\end{array}$ & $\begin{array}{c}\text { Scale Variance if Item } \\
\text { Deleted }\end{array}$ & $\begin{array}{c}\text { Corrected Item-Total } \\
\text { Correlation }\end{array}$ \\
\hline item_1 & 16.55 & 4.250 & .590 \\
item_2 & 16.28 & 4.376 & .568 \\
item_3 & 16.64 & 4.466 & .511 \\
item_4 & 16.51 & 4.274 & .618 \\
item_5 & 16.80 & 3.906 & .588 \\
\hline
\end{tabular}

Dari tabel tersebut dapat diambil kesimpulan bahwa semua pertanyaan variabel gaya kepemimpinan dapat dikatakan valid karena Corrected Item-Total Correlation melebihi 0,3 sehingga dapat dilanjutkan untuk penelitian lebih lanjut.

\section{Disiplin Kerja}

Dari data yang diperoleh berdasarkan jawaban responden maka dapat dilihat untuk variabel disiplin kerja nilai validitasnya seperti yang dikemukanan pada table 2.

Tabel 2

Uji Validitas Disiplin Kerja (X2)

\begin{tabular}{|l|c|c|c|}
\hline & $\begin{array}{c}\text { Scale Mean if Item } \\
\text { Deleted }\end{array}$ & $\begin{array}{c}\text { Scale Variance if Item } \\
\text { Deleted }\end{array}$ & $\begin{array}{c}\text { Corrected Item-Total } \\
\text { Correlation }\end{array}$ \\
\hline item_1 & 12.16 & 2.219 & .578 \\
item_2 & 12.32 & 2.920 & .610 \\
item_3 & 12.23 & 2.988 & .520 \\
item_4 & 12.15 & 2.744 & .714 \\
\hline
\end{tabular}

Sumber : Data diolah SPSS 16

Dari tabel tersebut dapat diambil kesimpulan bahwa terdapat 1 butir pertanyaan disiplin kerjayang dapat dikatakan tidak valid yaitu pertanyaan nomor 5. Karena Corrected Item-Total Correlationtidak melebihi 0,3 sehingga tidak 
dapat digunakan untuk penelitian lebih lanjut sedangkan untuk 4 butir pertanyaan lainnya dapat dikatakan valid karena Corrected Item-Total Correlation melebihi 0,3 sehingga dapat digunakan untuk penelitian lebih lanjut.

\section{Kinerja Karyawan (Y)}

Dari data yang diperoleh berdasarkan jawaban responden maka dapat dilihat untuk variabel kinerja karyawan nilai validitasnya seperti yang dikemukanan pada tabel 3 .

Tabel 3

Uji Validitas Kinerja Karyawan (Y)

\begin{tabular}{|c|c|c|c|}
\hline & $\begin{array}{c}\text { Scale Mean if Item } \\
\text { Deleted }\end{array}$ & $\begin{array}{c}\text { Scale Variance if Item } \\
\text { Deleted }\end{array}$ & $\begin{array}{c}\text { Corrected Item-Total } \\
\text { Correlation }\end{array}$ \\
\hline item_1 & 16.05 & 3.774 & .584 \\
item_2 & 16.09 & 3.810 & .588 \\
item_3 & 15.74 & 4.409 & .550 \\
item_4 & 15.75 & 3.957 & .645 \\
item_5 & 15.69 & 4.065 & .648 \\
\hline
\end{tabular}

Sumber: Data diolah SPSS 16

Dari tabel tersebut dapat diambil kesimpulan bahwa semua pertanyaan variabel kinerja karyawan dapat dikatakan valid karena Corrected Item-Total Correlation melebihi 0,3 sehingga dapat dilanjutkan untuk penelitian lebih lanjut.

\section{Motivasi Kerja (M)}

Dari data yang diperoleh berdasarkan jawaban responden maka dapat dilihat untuk variabel Disiplin Kerja nilai validitasnya seperti yang dikemukanan pada tabel 4.

Tabel 4

\section{Uji Validitas Motivasi Kerja (M)}

\begin{tabular}{|c|c|c|c|}
\hline & $\begin{array}{c}\text { Scale Mean if Item } \\
\text { Deleted }\end{array}$ & $\begin{array}{c}\text { Scale Variance if Item } \\
\text { Deleted }\end{array}$ & $\begin{array}{c}\text { Corrected Item-Total } \\
\text { Correlation }\end{array}$ \\
\hline item_1 & 16.68 & 3.389 & .507 \\
item_2 & 16.85 & 3.574 & .541 \\
item_3 & 16.92 & 3.057 & .633 \\
item_4 & 16.66 & 3.375 & .462 \\
item_5 & 17.01 & 3.181 & .409 \\
\hline
\end{tabular}

Sumber : Data diolah SPSS 16

Dari tabel tersebut dapat diambil kesimpulan bahwa semua pertanyaan variabel motivasi kerja dapat dikatakan valid karena Corrected Item-Total Correlation melebihi 0,3 sehingga dapat dilanjutkan untuk penelitian lebih lanjut.

\section{Uji Reliabilitas}

Uji reliabilitas digunakan untuk menguji sejauh mana keandalan suatu alat pengukur untuk dapat digunakan lagi untuk penelitian yang sama. Pengujian reliabilitas dalam penelitian ini adalah dengan menggunakan rumus Alpha. Hasil pengujian reliabilitas untuk masing-masing variabel yang diringkas pada tabel 5 . berikut ini:

\section{Tabel 5}

Hasil Uji Reliabilitas Variabel

Gaya Kepemimpinan, Disiplin Kerja, Kinerja, dan Motivasi Kerja

\begin{tabular}{|l|c|c|c|}
\hline No & Variabel & Cronbach's Alpha & Reliabilitas \\
\hline 1. & Gaya Kepemimpinan & 0,793 & Reliabel \\
\hline
\end{tabular}




\begin{tabular}{|l|l|l|l|} 
2. & Disiplin Kerja & 0,781 & Reliabel \\
\hline 3. & Kinerja Karyawan & 0,810 & Reliabel \\
\hline 4. & Motivasi Kerja & 0,738 & Reliabel \\
\hline
\end{tabular}
Sumber : Data diolah SPSS 16

Dari tabel 5 dapat diambil kesimpulan bahwa dari uji reliabilitas dihasilkan nilai Cronbach's Alphauntuk variabel penelitian yaitu Gaya Kepemimpinan, Disiplin Kerja, Kinerja Karyawan dan Motivasi Kerja lebih dari 0,60 yang memberikan hasil bahwa variabel yang diteliti memenuhi syarat konsistensi ( reliabilitas ). Jadi item - item pertanyaan untuk variabel penelitian dapat dipakai sebagai alat ukur dalam penelitian.

Uji Normalitas dilakukan untuk menguji apakah dalam sebuah model regresi variabel independen dan variabel dependenmemiliki ditribusi normal atau tidak. Data dikatakan berdistribusi normal apabila Asymp Sig (2-tailed )lebih besar dari level of significant yang dipakai yaitu 0,05 . Hasil penelitian menujukan nilai signifikansi sebesar $0,518(0,518>0,05)$. Hal ini berarti model regresi berdistribusi normal. Hasil pengujian normalitas dapat dilihat pada tabel berikut ini:

\section{Tabel 6}

Hasil Uji Normalitas

One-Sample Kolmogorov-Smirnov Test

\begin{tabular}{|c|c|c|}
\hline & Unstandardized Residual \\
\hline $\mathrm{N}$ & & 95 \\
\hline Normal Parameters ${ }^{a}$ & Mean & .0000000 \\
\hline & Std. Deviation & 1.74126478 \\
\hline Most Extreme & Absolute & .084 \\
\hline Differences & Positive & .084 \\
\hline & Negative & -.045 \\
\hline Kolmogorov-Smirnov & & .816 \\
\hline Asymp. Sig. (2-tailed) & & .518 \\
\hline
\end{tabular}

Sumber: Data diolah SPSS 16

\section{Uji Multikolinearitas}

Pengujian multikolinieritas bertujuan untuk mengetahui hubungan yangsempurna antar variabel bebas dalam model regresi. Gejala multikolinieritas dapatdilihat dari nilai tolerance dan nilai Varian Inflation Factor (VIF). Bila nilai VIFlebih kecil dari 10 dan nilai toleransinya di atas 0,1 atau $10 \%$ maka dapatdisimpulkan bahwa model regresi tersebut tidak terjadi multikolinieritas (Ghozali,2005).

Tabel 7

Hasil Uji Multikolinearitas

\begin{tabular}{|c|l|c|c|}
\hline No & \multicolumn{1}{|c|}{ Variabel Bebas } & Nilai Tolerance & Nilai VIF \% \\
\hline 1 & Gaya Kepemimpinan $(\mathrm{X} 1)$ & 0,852 & 1.174 \\
\hline 2 & Disiplin Kerja (X2) & 0,852 & 1.174 \\
\hline
\end{tabular}

Sumber: lampiran Output SPSS 16

Dari tabel tersebut menunjukkan bahwa nilai VIF semua variabel bebas dalampenelitian ini lebih kecil dari 10 sedangkan nilai toleransi semua variabel bebas lebihdari $10 \%$ yang berarti tidak terjadi korelasi antar variabel bebas yang 
nilainya lebihdari $90 \%$, dengan demikian dapat disimpulkan bahwa tidak terdapat gejalamultikolinieritas antar variabel bebas dalam model regresi

\section{Uji Heterokedastisitas}

Uji ini bertujuan untuk menguji apakah dalam sebuah model regresi terjadiketidaksamaan varians dari residual, dari satu pengamatan ke pengamatan yang lain.Jika varians dari residual dari satu pengamatan ke pengamatan yang lain tetap, makadisebut homoskedastisitas dan jika varians berbeda, disebut heterokedastisitas. Modelregresi yang baik adalah tidak terjadi heterokedastisitas. Untuk mendeteksi adatidaknya heterokedastisitas dapat digunakan metode grafik Scatterplot yangdihasilkan dari output program SPSS versi 16, Apabila pada gambar menunjukkanbahwa titik-titik menyebar secara acak serta tersebar baik di atas maupun di bawahangka 0 pada sumbu Y, maka hal ini dapat disimpulkan tidak terjadi adanya heterokedastisitas pada model regresi (Ghozali, 2005).

\section{Tabel 8}

Hasil Uji Heterokedastisitas

Scatterplot

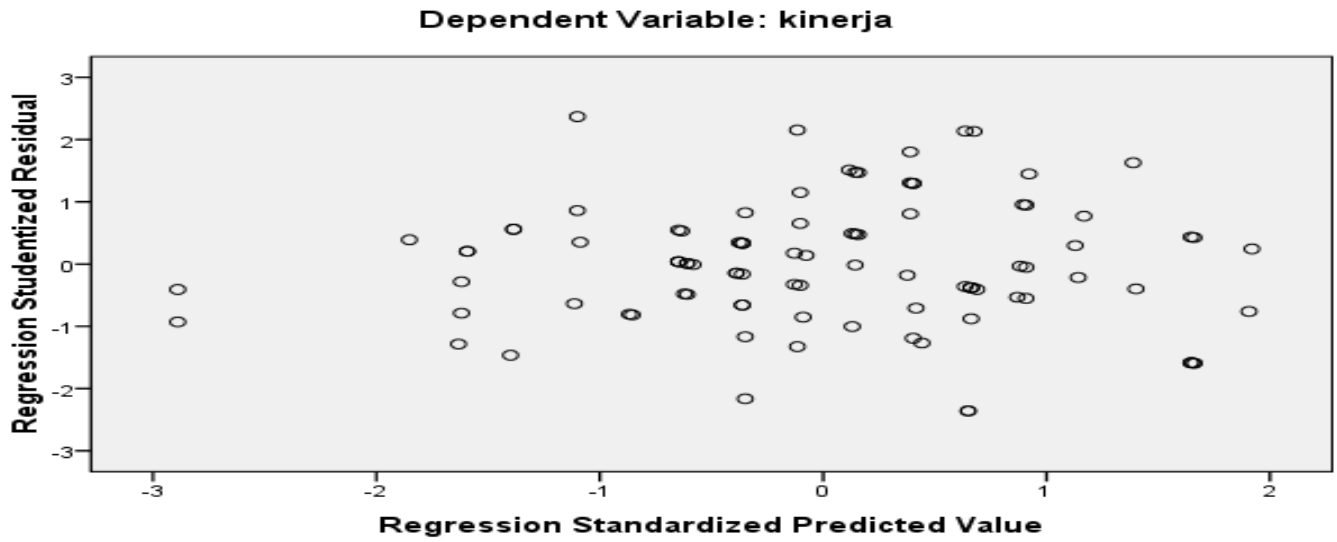

Sumber : Lampiran Output SPSS 16

Dari grafik tersebut terlihat titik-titik yang menyebar secara acak, tidakmembentuk suatu pola tertentu yang jelas, serta tersebar baik di atas maupun dibawah angka 0 (nol) pada sumbu Y, hal ini berarti tidak terjadi penyimpangan asumsiklasik heterokedastisitas pada model regresi yang dibuat, dengan kata lain menerimahipotesis homoskedastisitas.

Hasil analisis regresi linear sederhana yang diolah dengan mengunakan SPSS, diringkas pada tabel 9.

\section{Tabel 9 \\ Hasil Pengujian Persamaan Regresi Linear Sederhana (X1-M) Coefficients $^{a}$}

\begin{tabular}{|c|c|c|c|c|c|c|}
\hline \multirow{2}{*}{\multicolumn{2}{|c|}{ Model }} & \multicolumn{2}{|c|}{$\begin{array}{l}\text { Unstandardized } \\
\text { Coefficients }\end{array}$} & $\begin{array}{c}\text { Standardized } \\
\text { Coefficients }\end{array}$ & \multirow[b]{2}{*}{$\mathbf{T}$} & \multirow[b]{2}{*}{ Sig. } \\
\hline & & B & Std. Error & Beta & & \\
\hline 1 & (Constant) & 13.476 & 1.723 & & 7.819 & .000 \\
\hline & $\begin{array}{l}\text { Kepemimpin } \\
\text { an }\end{array}$ & .365 & .083 & .416 & 4.416 & .000 \\
\hline
\end{tabular}


Coefficients $^{\mathrm{a}}$

\begin{tabular}{|c|c|c|c|c|c|c|}
\hline \multirow{2}{*}{\multicolumn{2}{|c|}{ Model }} & \multicolumn{2}{|c|}{$\begin{array}{l}\text { Unstandardized } \\
\text { Coefficients }\end{array}$} & $\begin{array}{l}\text { Standardized } \\
\text { Coefficients }\end{array}$ & \multirow[b]{2}{*}{$\mathbf{T}$} & \multirow[b]{2}{*}{ Sig. } \\
\hline & & B & Std. Error & Beta & & \\
\hline 1 & (Constant) & 13.476 & 1.723 & & 7.819 & .000 \\
\hline & $\begin{array}{l}\text { Kepemimpin } \\
\text { an }\end{array}$ & .365 & .083 & .416 & 4.416 & .000 \\
\hline
\end{tabular}

a. Dependent Variable: motivasi

Sumber : Data diolah SPSS 16

Tabel 10

Hasil Pengujian Persamaan

Regresi Linear Sederhana (X2-M)

Coefficients $^{a}$

\begin{tabular}{|c|c|c|c|c|c|}
\hline \multirow[b]{2}{*}{ Model } & \multicolumn{2}{|c|}{$\begin{array}{l}\text { Unstandardized } \\
\text { Coefficients }\end{array}$} & $\begin{array}{l}\text { Standardized } \\
\text { Coefficients }\end{array}$ & \multirow[b]{2}{*}{$\mathrm{T}$} & \multirow[b]{2}{*}{ Sig. } \\
\hline & B & Std. Error & Beta & & \\
\hline 1 (Constant) & 11.687 & 1.885 & & 6.198 & .000 \\
\hline disiplin & .451 & .090 & .459 & 4.985 & .000 \\
\hline
\end{tabular}

a. Dependent Variable: motivasi

Sumber : Data diolah SPSS 16

Tabel 11

Hasil Pengujian Persamaan

Regresi Linear Sederhana (M-Y)

Coefficients $^{a}$

\begin{tabular}{|c|c|c|c|c|c|}
\hline \multirow[b]{2}{*}{ Model } & \multicolumn{2}{|c|}{$\begin{array}{l}\text { Unstandardized } \\
\text { Coefficients }\end{array}$} & \multirow{2}{*}{$\begin{array}{c}\begin{array}{c}\text { Standardized } \\
\text { Coefficients }\end{array} \\
\text { Beta }\end{array}$} & \multirow[b]{2}{*}{$\mathrm{T}$} & \multirow[b]{2}{*}{ Sig. } \\
\hline & $B$ & Std. Error & & & \\
\hline 1 (Constant) & 4.802 & 1.858 & & 2.585 & .011 \\
\hline motivasi & .715 & .088 & .645 & 8.134 & .000 \\
\hline
\end{tabular}

a. Dependent Variable: kinerja

Sumber: Data diolah SPSS 16

Tabel 12

Hasil Pengujian Persamaan

Regresi Linear Sederhana (X1-Y-M)

Coefficients $^{a}$

\begin{tabular}{|c|c|c|c|c|c|}
\hline \multirow[b]{2}{*}{ Model } & \multicolumn{2}{|c|}{$\begin{array}{c}\text { Unstandardized } \\
\text { Coefficients }\end{array}$} & \multirow{2}{*}{$\begin{array}{c}\begin{array}{c}\text { Standardized } \\
\text { Coefficients }\end{array} \\
\text { Beta }\end{array}$} & \multirow{2}{*}{$\mathrm{T}$} & \multirow[b]{2}{*}{ Sig. } \\
\hline & B & Std. Error & & & \\
\hline (Constant) & 10.110 & 1.839 & & 5.497 & .000 \\
\hline kepemimpinan & .470 & .088 & .483 & 5.324 & .000 \\
\hline (Constant) & 2.096 & 1.977 & & 1.060 & .292 \\
\hline kepemimpinan & .253 & .081 & .260 & 3.119 & .002 \\
\hline motivasi & .595 & .092 & .536 & 6.436 & .000 \\
\hline
\end{tabular}

a. Dependent Variable: kinerja

Tabel 13 
Hasil Pengujian Persamaan

Regresi Linear Sederhana (X2-Y-M)

Coefficients $^{a}$

\begin{tabular}{|c|c|c|c|c|c|}
\hline \multirow[b]{2}{*}{ Model } & \multicolumn{2}{|c|}{$\begin{array}{l}\text { Unstandardized } \\
\text { Coefficients }\end{array}$} & \multirow{2}{*}{$\begin{array}{c}\begin{array}{c}\text { Standardized } \\
\text { Coefficients }\end{array} \\
\text { Beta }\end{array}$} & \multirow[b]{2}{*}{$\mathrm{T}$} & \multirow[b]{2}{*}{ Sig. } \\
\hline & B & Std. Error & & & \\
\hline 1 (Constant) & 9.219 & 2.076 & & 4.441 & .000 \\
\hline disiplin & .512 & .100 & .470 & 5.142 & .000 \\
\hline 2 (Constant) & 2.183 & 2.077 & & 1.051 & .296 \\
\hline disiplin & .240 & .094 & .221 & 2.549 & .012 \\
\hline motivasi & .602 & .096 & .543 & 6.265 & .000 \\
\hline
\end{tabular}

a. Dependent Variable: kinerja

\section{Pengujian Hipotesis}

\section{Uji F (Pengujian Hipotesis Secara Silmultan)}

Untuk menguji pengaruh variabel bebas secara bersama-sama diuji dengan menggunakan uji F. Hasil perhitungan regresi secara simultan diperoleh sebagai berikut:

Tabel 14

Hasil Analisis Regresi Secara Silmultan ANOVA $^{\mathrm{D}}$

\begin{tabular}{|l|r|r|r|r|r|}
\hline Model & $\begin{array}{c}\text { Sum of } \\
\text { Squares }\end{array}$ & Df & Mean Square & F & Sig. \\
\hline 1 Regression & 276.297 & 3 & 92.099 & 29.406 & $.000^{\text {a }}$ \\
Residual & 285.008 & 91 & 3.132 & & \\
Total & 561.305 & 94 & & & \\
\hline
\end{tabular}

a. Predictors: (Constant), motivasi, kepemimpinan, disiplin

b. Dependent

Variable: kinerja

Sumber: Data diolah SPSS 16

Pengujian pengaruh variabel bebas secara bersama-sama terhadap variabelterikatnya dilakukan dengan menggunakan uji F. Dengan menggunakan batas signifikansi 0,05, maka diperoleh nilai signifikansi tersebut lebih kecil dari 0,05 . Hal ini berarti bahwahipotesis yang menyatakan bahwa secara simultan variabel gaya kepemimpinan,motivasi dan disiplin kerja mempunyai pengaruh terhadap kinerja karyawan.

\section{Analisis Koefisien Determinasi (R2)}

Koefisien determinasi merupakan besaran yang menunjukkan besarnya variasivariabel dependen yang dapat dijelaskan oleh variable independennya. Dengan katalain, koefisien determinasi ini digunakan untuk mengukur seberapa jauh variabelvariabelbebas dalam menerangkan variabel terikatnya. Nilai koefisien determinasiditentukan dengan nilai adjusted $R$ square sebagaimana dapat dilihat pada tabel 15

Tabel 15

Koefisien Determinasi

Model Summary 


\begin{tabular}{|l|r|r|r|r|}
\hline Model & \multicolumn{1}{|c|}{ R } & \multicolumn{1}{|c|}{ R Square } & Adjusted R Square & Std. Error of the Estimate \\
\hline 1 & $.702^{\mathrm{a}}$ & .492 & .476 & 1.770 \\
\hline
\end{tabular}

a. Predictors: (Constant), motivasi, kepemimpinan, disiplin

Sumber: Data diolah SPSS 16

Hasil perhitungan regresi dapat diketahui bahwa koefisien determinasi(adjusted $R 2$ ) yang diperoleh sebesar 0,48 . Hal ini berarti $48 \%$ variasi variabel kinerjakaryawan dapat dijelaskan oleh variabel gaya kepemimpinan, motivasi dan disiplinkerja, sedangkan sisanya sebesar $52 \%$ diterangkan oleh variabel lain yang tidakdiajukan dalam penelitian ini.

\section{Uji t (Uji signifikasi Pengaruh Parsial)}

Hipotesis 1, 2, 3, 4 dan 5 dalam penelitian ini diuji kebenarannya denganmenggunakan uji parsial. Pengujian dilakukan dengan melihat taraf signifikansi (pvalue),jika taraf signifikansi yang dihasilkan dari perhitungan di bawah 0,05 makahipotesis diterima, sebaliknya jika taraf signifikansi hasil hitung lebih besar dari 0,05maka hipotesis ditolak.

Tabel 16

Hasil Uji T Secara Parsial Coefficients $^{\mathrm{a}}$

\begin{tabular}{|c|c|c|c|c|c|}
\hline \multirow[b]{2}{*}{ Model } & \multicolumn{2}{|c|}{ Unstandardized Coefficients } & \multirow{2}{*}{$\begin{array}{c}\text { Standardized } \\
\text { Coefficients }\end{array}$} & \multirow[b]{2}{*}{$\mathrm{T}$} & \multirow[b]{2}{*}{ Sig. } \\
\hline & $\mathrm{B}$ & Std. Error & & & \\
\hline 1 (Constant) & .526 & 2.112 & & .249 & .804 \\
\hline kepemimpinan & .215 & .082 & .221 & 2.610 & .011 \\
\hline Disiplin & .181 & .094 & .167 & 1.926 & .057 \\
\hline Motivasi & .528 & .097 & .476 & 5.416 & .000 \\
\hline
\end{tabular}

a. Dependent Variable: kinerja

Sumber: Data diolah SPSS 16

Dari tabel dapat diketahui nilai signifikan untuk variabel Gaya Kepemimpinan adalah 0,11 dan variabel disiplin kerja adalah 0,57. Hal ini berarti signifikan $t$ lebih besar dari 0,05 yang menunjukkan ada pengaruh yang positif dan signifikan antara gaya kepemimpinan dan disiplin kerja dengan kinerja karyawan secara parsial. Jadi hipotesis diterima dan dapat disimpulkan bahwa gaya kepemimpinan dan disiplin kerja berpengaruh signifikan terhadap kinerja karyawan PT. Semen Padang.

Pada tahapan pengujian hipotesis t-statistik untuk variabek motivasi diperoleh nilai signifikansi hasil pengolahan data adalah sebesar 0,000 tahapan pengolahan data dilakukan dengan menggunakan tingkat kesalahan sebesar 0,05. Dengan demikian terlihat bahwa nilai sig 0,000 lebih kecil dari nilai alpha 0,05 maka keputusanya adalah Ho ditolak dan Ha diterima sehingga dapat disimpulkan bahwa motivasi kerja berpengaruh signifikan terhadap kinerja karyawan

\section{PEMBAHASAN}

Berdasarkan hasil pengujian secara statistik dapat terlihat dengan jelas bahwa secara parsial (individu) semua variabel bebas berpengaruh terhadap variabel terikat. Pengaruh yang diberikan kedua variabel bebas tersebut bersifat positif artinya semakin tinggi gaya kepemimpinan dan disiplin kerja maka mengakibatkansemakin tinggi pula kinerja karyawan yang dihasilkan. Hasil 
tersebut sesuai dengan hipotesis yang diajukan. Hasil penelitian ini juga sesuai dengan hasil penelitian sebelumnya. Penjelasan dari masing-masing pengaruh variabel dijelaskan sebagai berikut:

\section{Pengaruh Gaya Kepemimpinan Terhadap Motivasi}

Hasil pengujian hipotesis telah membuktikan terdapat pengaruh antara gaya kepemimpinan terhadap motivasi kerja karyawan. Melalui hasil perhitungan yang telah dilakukan diperoleh nilai t hitung sebesar 4.416 dengan taraf signifikansi hasil sebesar 0,00 tersebut lebih kecil dari 0,05, dengan demikian Ha diterima dan Ho ditolak. Pengujian ini secara statistik membuktikan bahwa gaya kepemimpinan berpengaruh positif dan signifikan terhadap motivasi karyawan. Artinya bahwa ada pengaruh antara variabel gaya kepemimpinan terhadap motivasi kerja karyawan di PT Semen Padang.

\section{Pengaruh Disiplin Kerja Terhadap Motivasi Kerja}

Hasil pengujian hipotesis telah membuktikan terdapat pengaruh antara disiplin kerja terhadap motivasi kerja. Melalui hasil perhitungan yang telah dilakukandiperoleh nilai t hitung sebesar 4,985 dengan taraf signifikansi hasil sebesar 0,000 tersebut lebih kecil dari 0,05, yang berarti bahwa hipotesis dalam penelitian ini menerima $\mathrm{Ha}$ dan menolak Ho. Pengujian ini secara statistik membuktikan bahwa motivasi berpengaruh positif terhadap kinerja karyawan. Artinya bahwa ada pengaruhantara variabel motivasi terhadap kinerja karyawan di PT Semen Padang.

\section{Pengaruh Motivasi Terhadap Knerja Karyawan}

Hasil pengujian hipotesis telah membuktikan terdapat pengaruh antara motivasi terhadap kinerja karyawan. Melalui hasil perhitungan yang telah dilakukan didapat nilai t hitung sebesar 8,134 dengan taraf signifikansi hitung sebesar 0,00 tersebut lebih kecil dari 0,05, yang berarti bahwa hipotesis dalam penelitian ini menerima Ha dan menolak Ho. Pengujian ini secara statistik membuktikan bahwa motivasi berpengaruh positif terhadap kinerja karyawan. Artinya bahwa ada pengaruh antara variabel motivasi terhadap kinerja karyawan di PT Semen Padang.

\section{Pengaruh Gaya Kepemimpinan Terhadap Kinerja Karyawan yang Dimediasi Oleh Motivasi}

Hasil pengujian hipotesis telah membuktikan terdapat pengaruh antara gaya kepemimpinan terhadap kinerja karyawan yang dimediasi oleh motivasi. Melalui hasil perhitungan yang telah dilakukan diperoleh nilai t hitung sebesar 3,119 untuk gaya kepemimpinan dan 6,436 untuk motivasi dengan taraf signifikansi hasil sebesar 0,00 tersebut lebih kecil dari 0,05, dengan demikian Ha diterima dan Ho ditolak. Pengujian ini secara statistik membuktikan bahwa gaya kepemimpinan berpengaruh positif dan signifikan terhadap kinerja karyawan yang dimediasi oleh motivasi .Artinya bahwa ada pengaruh antara variabel gaya kepemimpinan terhadap kinerja karyawan yang dimediasi oleh motivasi di PT Semen Padang.

\section{Pengaruh Disiplin Kerja Terhadap Kinerja Karyawan yang Dimediasi Oleh Motivasi}

Hasil pengujian hipotesis telah membuktikan terdapat pengaruh antara disiplin kerja terhadap kinerja karyawan yang dimediasi oleh motivasi. Melalui hasil perhitungan yang telah dilakukan diperoleh nilai t hitung sebesar 2,549 untuk disiplin kerja dan 6,265 untuk motivasi dengan taraf signifikansi hasil 
sebesar 0,00 tersebut lebih kecil dari 0,05, dengan demikian Ha diterima dan Ho ditolak. Pengujian ini secara statistik membuktikan bahwa disiplin kerja berpengaruh positif dan signifikan terhadap kinerja karyawan yang dimediasi oleh motivasi .Artinya bahwa ada pengaruh antara variabel disiplin kerja terhadap kinerja karyawan yang dimediasi oleh motivasi di PT Semen Padang.

Dari data primer yang diperoleh dari penyebaran kuesioner maka dilakukanpengujian reliabilitas untuk mengetahui bahwa jawaban responden terhadappernyataan konsisten dari waktu ke waktu. Dan dilakukan pengujian validitas untukmengukur sah tidaknya suatu kuesioner. Hasil dari uji reliabilitas dan validitasmenunjukkan bahwa seluruh pernyataan dalam setiap variabel reliabel dan valid.Dalam uji asumsi klasik yang meliputi uji multikolonieritas, ujiheteroskedastisitas dan uji normalitas menunjukkan bahwa dalam model regresi tidakditemukan adanya korelasi antar variabel bebas dan tidak terjadi heteroskedastisitasserta memiliki distribusi normal.

\section{SIMPULAN}

1. Hasil pengujian hipotesis telah membuktikan terdapat pengaruh antara gaya kepemimpinan terhadap motivasi kerja karyawan. Melalui hasil perhitungan yang telah dilakukan diperoleh nilai t hitung sebesar 4.416 dengan taraf signifikansi hasil sebesar 0,00 tersebut lebih kecil dari 0,05, dengan demikian Ha diterima dan Ho ditolak.

2. Hasil pengujian hipotesis telah membuktikan terdapat pengaruh antara disiplin kerja terhadap motivasi kerja. Melalui hasil perhitungan yang telah dilakukandiperoleh nilai t hitung sebesar 4,985 dengan taraf signifikansi hasil sebesar 0,000 tersebut lebih kecil dari 0,05, yang berarti bahwa hipotesis dalam penelitian ini menerima Ha dan menolak Ho.

3. Hasil pengujian hipotesis telah membuktikan terdapat pengaruh antara motivasi terhadap kinerja karyawan. Melalui hasil perhitungan yang telah dilakukan didapat nilai t hitung sebesar 8,134 dengan taraf signifikansi hitung sebesar 0,00 tersebut lebih kecil dari 0,05, yang berarti bahwa hipotesis dalam penelitian ini menerima Ha dan menolak Ho.

4. Hasil pengujian hipotesis telah membuktikan terdapat pengaruh antara gaya kepemimpinan terhadap kinerja karyawan yang dimediasi oleh motivasi. Melalui hasil perhitungan yang telah dilakukan diperoleh nilai $\mathrm{t}$ hitung sebesar 3,119 untuk gaya kepemimpinan dan 6,436 untuk motivasi dengan taraf signifikansi hasil sebesar 0,00 tersebut lebih kecil dari 0,05, dengan demikian Ha diterima dan Ho ditolak. 5. Hasil pengujian hipotesis telah membuktikan terdapat pengaruh antara disiplin kerja terhadap kinerja karyawan yang dimediasi oleh motivasi. Melalui hasil perhitungan yang telah dilakukan diperoleh nilai t hitung sebesar 2,549 untuk disiplin kerja dan 6,265 untuk motivasi dengan taraf signifikansi hasil sebesar 0,00 tersebut lebih kecil dari 0,05, dengan demikian $\mathrm{Ha}$ diterima dan Ho ditolak. 


\section{DAFTAR PUSTAKA}

Anoroga, Panji. 2001. Psikologi Kepemimpinan. Semarang: Rineka Cipta

Abdurrahmat Fathoni. 2006. Manajemen Sumber Daya Manusia. Bandung : Rineka Cipta

Aldi, Y., \& Susanti, F. (2019). Pengaruh Stress Kerja Dan Motivasi Kerja Terhadap Prestasi Kerja Karyawan Pada PT. Frisian Flag Indonesia Wilayah Padang. https://doi.org/10.31227/osf.io/et4rn

Ardana, I Komang, Ni Wayan Mujiati, I Wayan Mudiartha Utama. 2012. Manajemen Sumber Daya Manusia. Edisi Pertama. Graha Ilmu.Yogyakarta

Fendi, Z., \& Susanti, F. (2018). Pengaruh Kepuasan Kerja Terhadap Turnover Intention Dengan Komitmen Organisasi Sebagai Variabel Intervening Pada CV. Belibis Pariaman. https://doi.org/10.31227/osf.io/wumgx

Hani, Handoko T. 2008. Manajemen Personalia dan Sumber Daya Manusia.BPFE : Yogyakarta

Hasibuan. ( 2010). Manajemen Sumber Daya Manusia.Jakarta: Bumi Aksara.

Hengki febrianto. (2014). Manajemen Sumber Daya Manusia.Padang

Lubis, A. Y. O., \& Susanti, F. (2019). Pengaruh Gaya Kepemimpinan Dan Kompensasi Terhadap Prestasi Kerja Karyawan (Studi pada PT Japfa Comfeed Indonesia (JCI) Tbk Devisi Fam 1. https://doi.org/10.31227/osf.io/7tbrg

Junaidi, R., \& Susanti, F. (2019). Pengaruh Gaya Kepemimpinan Dan Budaya Organisasi Terhadap Kinerja Pegawai Pada UPTD Baltekkomdik Dinas Pendidikan Provinsi Sumatera Barat. https://doi.org/10.31227/osf.io/bzq75

Luthans,Fred. 2005. Perilaku Organisasi (organization behavior $10^{\text {th }}$ ). terj :Vivin Andhika Yuwono at all.edisi 10.Yogyakarta.ANDI

Luthans,Fred.2006. Perilaku Organisasi .Alih Bahasa V.A Yuwono.Yogyakarta:Andi

M, Manullang. 2006. Manajemen Personalia. Jakarta : PT. Ghalia Indonesia.

Mathis, dan Jackson. 2002. Manajemen Sumber Daya Manusia. Edisi pertama. Cetakan Pertama. Yogyakarta : Salemba Empat 
Moeheriono.2010. Pengukuran Kinerja Berbasis Kompetensi. Surabaya: Galia Indonesia

Nurlaila, 2010. Manajemen Sumber Daya Manusia I. Ternate: Penerbit LepKhair

Regina Aditya, (2010). Manajemen Sumber Daya Manusia.Yogyakarta

Ridho, M., \& Susanti, F. (2019). Pengaruh Stres Kerja Dan Motivasi Kerja Terhadap Kepuasan Kerja Pada Karyawan Bank Mandiri Syariah Cabang Padang. https://doi.org/10.31227/osf.io/pa2cg

Robbins SP, at al, 2006.Perilaku Organisasi edisi 12.Jakarta : Salemba Empat

Robbin Stephen P.-Judge Timothy A., 2012.Perilaku Organisasi, Edisi 12 :Salemba Empat, Jakarta

Susanto, R. (2018). Pengawasan Dan Lingkungan Kerja Terhadap Kinerja Karyawan PT. Bussan Auto Finance. https://doi.org/10.31227/osf.io/m3kge

Triantoro, Safaria. 2004. "Kepemimpinan”. Edisi Pertama. Graha Ilmu. Yogyakarta.

Yudistira, D. S., \& Susanti, F. (2019). Pengaruh Motivasi Kerja Dan Budaya Kerja Terhadap Kinerja Karyawan Dinas Pemberdayaan Masyarakat Dan Desa, Pengendalian Penduduk Dan Keluarga Berencana Kabupaten Pesisir Selatan. https://doi.org/10.31227/osf.io/jk54m 